\title{
Piggy in the middle
}

Backing the right horse in China vs USA

The focus of global geo-
political power sits squarely
within the Asia-Pacific region,
but China's rise has resulted
in face-off with the United
States. Canadian foreign policy
has three main options in light
of China's rise to dominance:
pivot to China, place itself
equidistance between Beijing
and Washington, or align with
the US strategy. Professor
Kenneth Holland of O.P. Jindal
Global University argues that
Canada's national interest
would be best served by
broadly aligning with the
United States. However,
it should also cultivate its
relationships with other
emerging economies and
advocate to moderate
Washington's bellicose strategy
in the Pacific.

in the Pacific.

\section{$\mathrm{H}^{2}$ \\ THE STATUS QUO}

order. Pax Britannica, extending

from the end of the Napoleonic

Wars (early 1800s) to the start of the

First World War (1914), saw British

hegemonic power dominate global

geopolitics. In the early $20^{\text {th }}$ century, this
gave way to Pax Americana, with the

Uniled States gaining economic and

itself the 'world's policeman'. However,

as ever, the winds of change continue to

blow, and in recent years have risen to

geo-political power now sits squarely

within the Asia-Pacific region, resulting

in a face-off between the United States

for dominance are the world's remaining 193 sovereign states.

The approach of the Trump

administration, which shifted US

policy from engagement and dialogue

with China towards a more hard-line

stance (economically and militarily),

has been adopted by the new Biden

administration. Washington's posture

toward Beljing has put traditional US

Jindal Global University, Professor

Kenneth Holland is looking at how

Canada, whose largest and second

largest trading partners are the United

States and China, respectively, is picking its way through this things, China's rise. enue in Canada. gave way to Pax Americana, with the

a deafening howl. The focus of global

and China. In the middle of this battle eign policy with respect Sino-Canadian relations cannot be Whed in isolation from its relationship Un the United States, or from the Chins (not between the US and China (not to mention the myriad Connections among these three players and other sovereign states). tis a complexweb of considerations geopolitics shaped by, among other

China and Canada have shared a diplomatic relationship for the last 50 years. Over this time, the volume of trade from China to Canada has gone from $\$ 150$ million to $\$ 74$ billion; in the opposite direction, $4 \%$ of Canadian exports go to China. This trade is generally well balanced and complementary; Canada

provides natural resources in return for manufactured goods. Chinese tourists, students, and foreign ortant sources of

From the Canadian perspective, this relationship is only outdone by that it shares with the United States, with he two countries enjoying the world's largest trading relationship (worth lion). In 2019 the cross-border trade in

\section{takes, to align wh} the US or with China or with neither, will shape its position in the world for reseatchoutreach.org

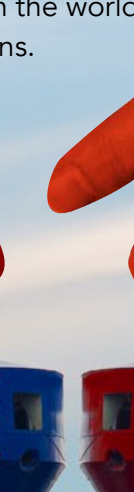

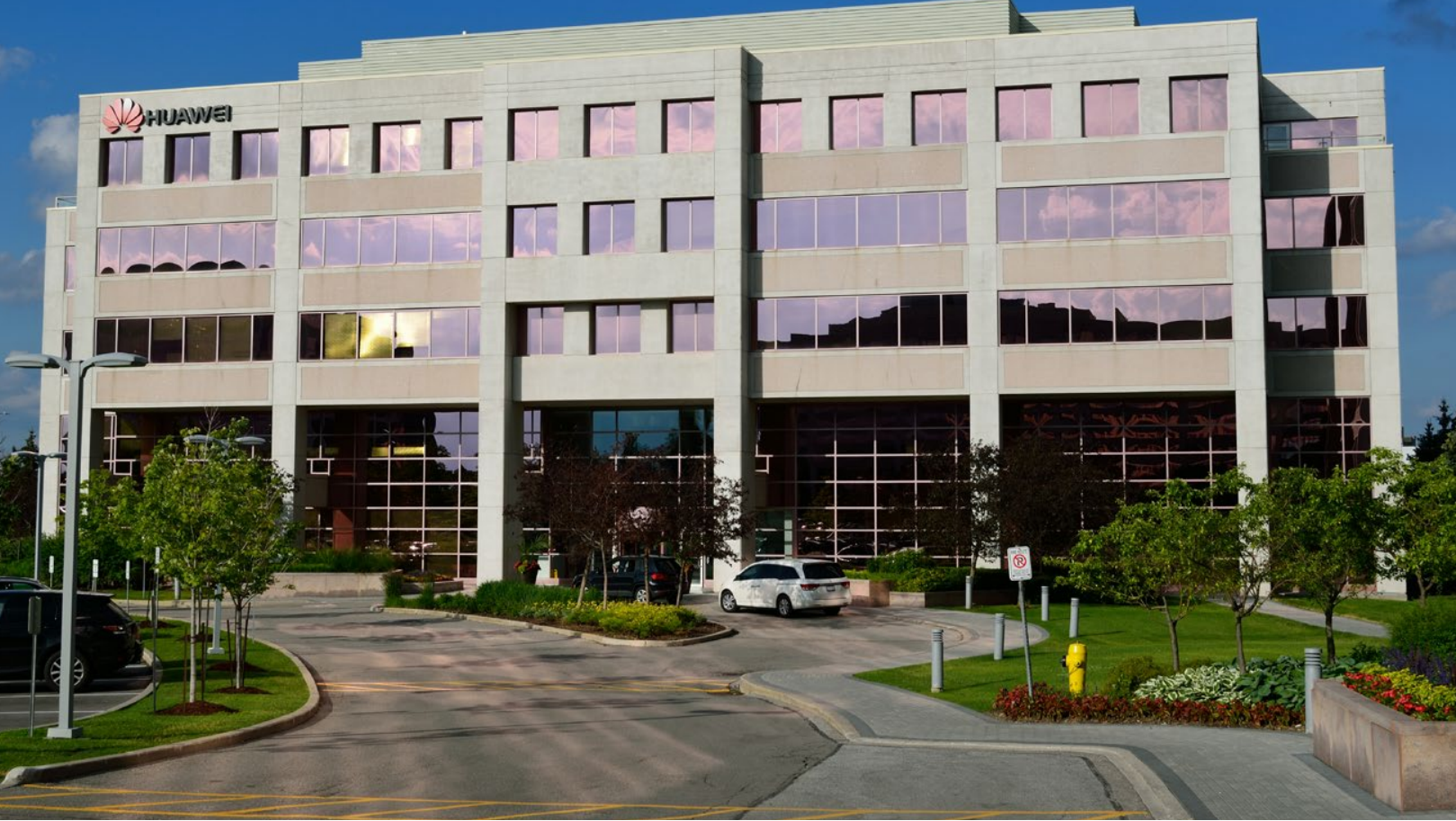

goods and services was worth $\$ 704$ billion alone, not to mention money flowing through investments. Some 3 million Canadian jobs rely on these exports, and $20 \%$ of the country's Gross Domestic Product (GDP) is based on the export of goods to the US. Moreover, the diplomatic and politica ties are deep and profound; Canadian in US troops have stood side-by-side last century, and both are founding North Atlantic Treaty Organization (NATO). Recent years have seen some damage to this longstanding friendship, owing mostly to the election and subsequent policies of the Trump administration (eg, the introduction of tariffs on some Canadian goods). With the arrival of the Biden administration, reconciliation is on the horizon, but the a sicky question of China coulc spanner in the works.

LEFT, RIGHT, OR GO STRAIGHT ON Canada has three main options in light of China's rise to dominance: (1) pivot

to China, (2) place itself equidistance between Beijing and Washington, or (3) align with the US strategy.

Aligning with China would come with significant benefits, particularly if Chin prevails in its march towards globa hegemony, in short, Canada would benefit from backing the winning horse. Cand wisld look to model Europea

largest trading partner, and a country with whom they share a long and . unrelenting, ranging from tariffs and other trade barriers, border restrictions, and withdrawals from joint security and intelligence partnerships. The country could also suffer in the court of public opinion, wh crics accusing Ottawa of gnoring the regime's basic principles f democracy, huma

growing (political, economic, and military,) rivalry between the United Shes and China is one of the greatest the second option, of European nations global threats of the $21^{\text {st }}$ century.

of European nations Germany, would be

countries such as Greece and Hungary who treat China as a friend and strategic partner. To make this inten clear, they could develop formal polcies that support the current locus Chin China Sea region, going against the attempts of the US and Japan to bring the nations of the Indian Ocean further into the mix (ie, an Indo-Pacific focus). would be significant. Alienating their to take a more neutral stance. Active an Indo-Pacific approach, but with an emphasis on China as a partner rather than an adversary. Again, this option is not without its risks; by taking the middle ground, Canada could end up pleasing no one. In particular, the threa us would remain, while fayert of the economic ties with a vengeful $C$ hin may suffer. 


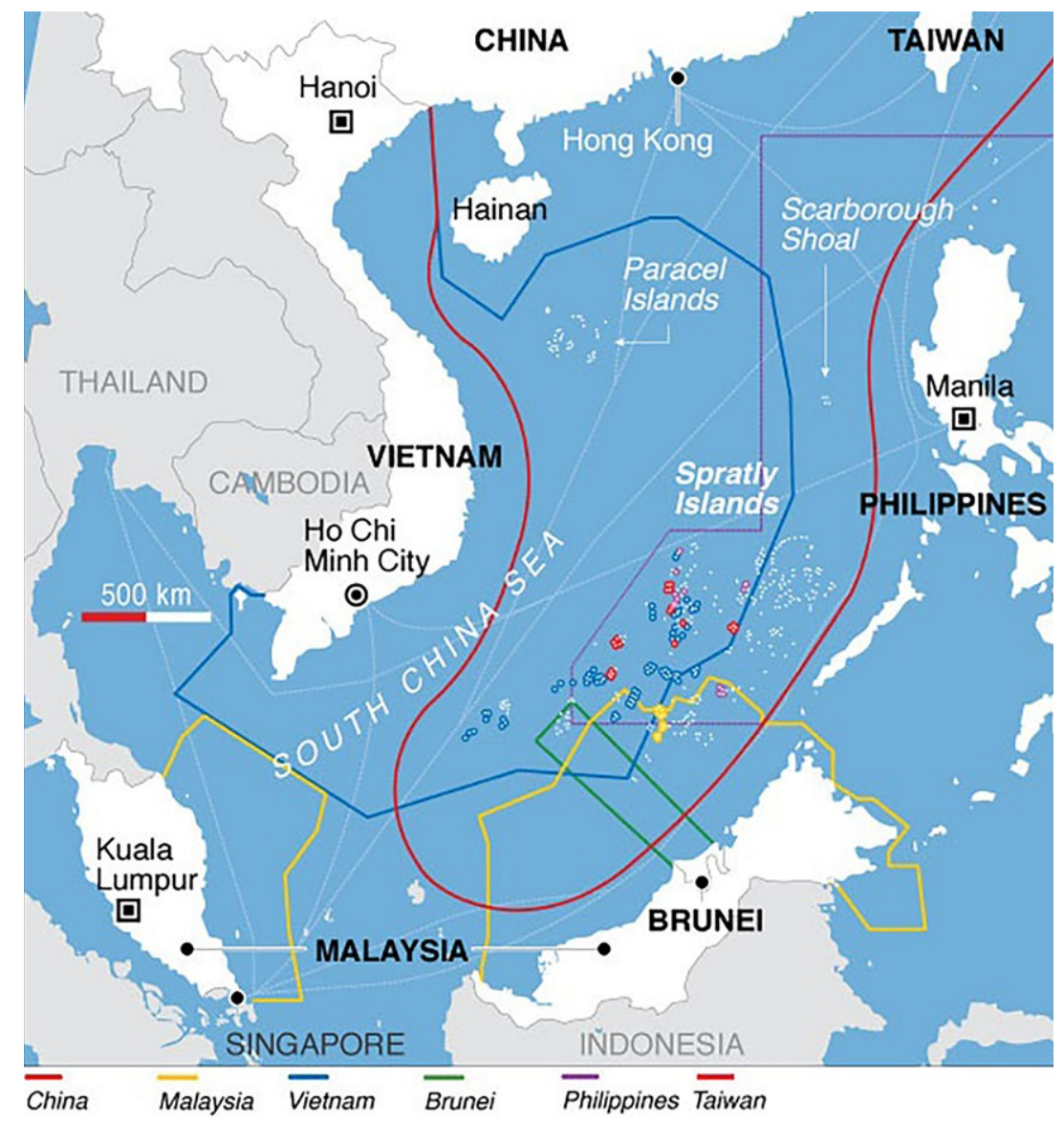

Territories in the South China sea.

The United States is Canada's most important ally, and its continued prosperity and security is intimately tied to this relationship.

A third and final choice would be for Canada to get on board with US policy, as have other allies such as would entail wholeheartedly adopting an Indo-Pacific approach and publicly opposing China's economic and militay march across the globe. Canada could look to join the Quadrilateral Security Alliance, an informal network of countries, including the United States, Japan, Australia, and India, who talk, share information, and conduct joint military exercises. The benefits of this approach would be the maintenance of good relations with the US, and the preservation of curent advantages in trade, border policies, security, amo Canada to curate closer relationships by promoting continued productive allies, including Japan, Australia, and South Korea, simultaneously balance their support for Washington's efforts to contain China's territorial expansionism and authoritarianism, with trade initiatives (eg, the Regional Comprehensive Economic Partnership that facilitate engagement with China within established international rules (eg, those of the World Trade Organisation, WTO). This course of action has become somewhat easier with the arrival of the Biden administration, which rejects Trump unilateral approach of imposing tariffs and sanctions on Beijing and is more likely to pursue its agenda through multilateral action (eg. international organisations).

\section{A NEW PLACE IN A NEW}

\section{WORLD ORDER}

The growing (political, economic, and military) rivalry between the United States and China is one of the greatest global threats of the 21st century. For countries caught in the middle, there re only tough choices.

Based on his analysis of the state-ofplay, Professor Holland argues that Canada's national interest would be best served by broadly aligning with the United States. The United States is Canada's most important ally, and its continued prosperity and security is intimately tied to this of the politica appear to be converging on a

consensus approach to China, allies such as Canada increasingly have little leverage to sway opinions. Cultivating and building on its relationships with other Asian economies, such as Japan, South Korea, India, and countries in Southeast Asia, could soften the blow of any potential deterioration in Canada's relationship with China. Professor Holland suggests that Canada joins Japan, Australia, and South Korea in advocating to moderate Washington's bellicose strategy in the Pacific, with the aim of pursuing more consistent multiateralism and preserving

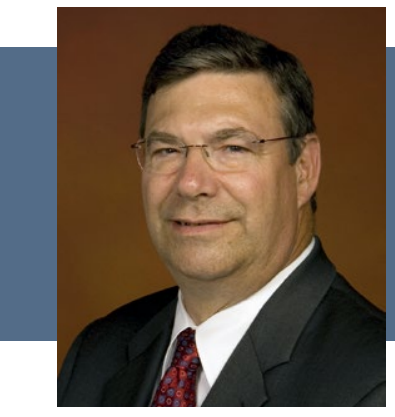

\section{Behind the Research}

\section{Professor Kenneth Holland}

E: kmholland62@gmail.com T: +1765 730-7744 W: https://iqu.irins.org/profile/203603

\section{Research Objectives}

Kenneth Holland specialises in establishing the rule of la in developing countries and the legal foundations of

\section{Detail}

2700 West Brayston Way

Muncie, Indiana 47304, USA

Kenneth Holland, Professor and Dean at O.P. Jindal Global University in Sonipat, India, earned a Ph.D. in Political Science from the University of Chicago. He is President Emeritus of the American University of Afghanistan and a Past President of the Association for anadian Studies in the United States.

\section{References}

Holland, KM (2021). Canada and the Indo-Pacific Strategy. Can. Foreign Pol. J. https://doi.org/10.1080/11 926422.2021 .1880949

Kenneth KM (2014). The Canada-United States defence relationship: a partnership for the twenty-first century, -246, https://doi.org/10.10 $80 / 11926422.2014 .995686$

(1) Canada's Can Foreign Pol J 18:1, 51-64, https//doiorg/10.1080 111926422.2012 .662615

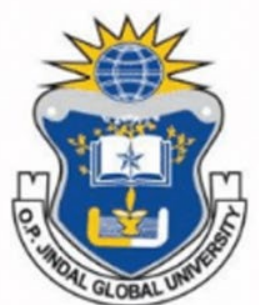

O.P. Jindal Global University Arivate Uniersity Promoting Public Serrice

\section{Personal Response} Ultimately, who do you think will be the victor
between China and the USA? Will China become th dominant super-power?

II Ultimately China will fail to supplant the United States as the world's sole superpower. China lacks military alliances, and its socialist market economy is unable to compete with Ameica's free market economy, which rewards technological innovation. Vladimir Putin is jealous
of China's rise and will take steps to limit Beijing's influence in the Arctic and other regions important to Russia's claim to be a great power. The coronavirus pandemic
has damaged China's standing in the world, and Beijing ambitious Belt and Road global infrastructure project
has been scaled back. China's labour force is decreasing and its population is ageing.

\section{The election and events of the Donald Trump} presidency showed us just how fragile our political systems really are. Is a time there can be wholesale regime change? Would Canada do better to align itself with more stable multicountry blocks such as the EU?

II The January 6, 2021, insurrection, intended to prevent the peaceful transfer of power from Donald America's democracy. The subsequent events, however, demonstrated the resiliency of its constitution. The United States remains the world's oldest democracy and a beacon for those living in authoritarian regimes. America remains the leader of the the ral rules-based World War. The European Union is not cohesive enough to assume responsibility for the survival of this order, wit its emphasis on human rights and freedom, that China seeks to destroy. 